\title{
CONSTITUTIONALE
}

Volume 2 Issue 2, July-December 2021: PP: 79-88

Faculty of Law, Universitas Lampung, Bandar Lampung, Indonesia.

http://jurnal.fh.unila.ac.id/index.php/constitutionale

P-ISSN: 2723-2492 E-ISSN: 2745-9322

\section{The Regulation of Continuous Election Design's Implementation Based on the Constitutional Court's Decision}

\author{
Aufa Naufal Rishanda \\ General Election Commission of Bandar Lampung, Indonesia \\ aufanaufarishamda@gmail.com
}

Submitted: Mar 5, 2021; Reviewed: Jul 27, 2021; Accepted: Sep 22, 2021

\begin{tabular}{|c|c|}
\hline Article's Information & Abstract \\
\hline Keywords: & Abstract \\
\hline $\begin{array}{l}\text { Original Intent; Election Judge's } \\
\text { Consideration; Simultaneously }\end{array}$ & $\begin{array}{l}\text { This study aims to describe the consistency of judges' } \\
\text { considerations in the Constitutional Court Decision No. }\end{array}$ \\
\hline $\begin{array}{l}\text { DOI } \\
\text { https://doi.org/10.25041/constitu } \\
\text { tionale.v2i2.2295 }\end{array}$ & $\begin{array}{l}\text { 14/PUU-XI/2013 and the Constitutional Court Decision No. } \\
55 / P U U \text {-XVII/2019 and its suitability with the design of the } \\
\text { election administration according to the } 1945 \text { Constitution } \\
\text { of the Republic of Indonesia. To measure the consistency of } \\
\text { the two Constitutional Court Decisions, the meaning of the } \\
\text { original intent of holding elections simultaneously } \\
\text { according to the Amendment of the } 1945 \text { Constitution of the } \\
\text { Republic of Indonesia will be used. This is normative legal } \\
\text { research, which uses approach legislation (statute } \\
\text { approach) and historical approach (historical approach). } \\
\text { The results of this study indicate that the judge's } \\
\text { considerations in the Constitutional Court Decision } \\
\text { 14/PUU-XI/2013 are inconsistent with the Constitutional } \\
\text { Court Decision 55/PUU-XVII/2019. Based on the original } \\
\text { intent study, the Amendrs to the 1945 Constitution of the } \\
\text { Republic of Indonesia disagreed on the simultaneous } \\
\text { implementation of the General Election in Indonesia. So the } \\
\text { judge's consideration in the Constitutional Court's decision } \\
\text { Number 14/PUU-XI/2013, which requires simultaneous } \\
\text { elections, is not following the design of the election } \\
\text { administration according to the amendment to the 1945 } \\
\text { Constitution of the Republic of Indonesia. Six alternatives } \\
\text { for the simultaneous implementation of elections. }\end{array}$ \\
\hline
\end{tabular}

Constitutionale is a journal published by the Faculty of Law, Universitas Lampung, under a

Creative Commons Attribution-ShareAlike 4.0 International License. 


\section{A. Introduction \\ 1. Background}

The Constitutional Court is a high state institution in the Indonesian constitutional system and the holder of judicial power with the legal basis of the third amendment to the 1945 Constitution of the Republic of Indonesia. ${ }^{1}$ As a state of law, Indonesia certainly carries out its government through a legal system starting from the 1945 Constitution as the highest law that the state is nothing but the embodiment of the legal order of a nation. ${ }^{2}$

Decisions of the Constitutional Court always contain the judge's considerations located at the end before the decision. Normatively, judges' considerations are binding and serve as the legal basis and arguments or reasons used by judges to be the basis for deciding cases in the Constitutional Court. Based on one of its powers, namely to examine the law against the 1945 Constitution of 1945, it was submitted to the Constitutional Court through the judges' consideration of the Constitutional Court Decision Number 14/PUU-XI/2013 and the Constitutional Court Decision Number 55/PUU-XVII/2019, regarding the different meanings of "simultaneously". "Election design arrangements. ${ }^{3}$

The characteristic of a democratic country is that most countries involve the community in planning and conducting general elections. ${ }^{4}$ The sustainability of democracy requires people who agree on the meaning of democracy, who understand how democracy works and its uses for life. Therefore, even though democracy is related to the issue of representation of the will of the people. ${ }^{5}$

General Elections is a democratic mechanism in the process to realize real people's sovereignty. Article 22E paragraph (1) of the 1945 Constitution of the Republic of Indonesia normatively explains that general elections must be held in a direct, general, free, secret, honest and fair manner every five years at the same time. However, it does not at all stipulate that the types of elections must be conducted simultaneously. or not simultaneously. ${ }^{6}$ It can be said that elections are basically not only about output but should also guarantee that the new elite will be far better than the elite it replaces. ${ }^{7}$ The principle of independence is the freedom to determine one's destiny and the right without any conditions to achieve noble ideals. ${ }^{8}$ So, to

\footnotetext{
1 Jimly Asshiddiqie, Kedudukan Mahkamah Konstitusi Dalam Struktur Ketatanegaraan Indonesia (Semarang: Pustaka Utama, 2015).

${ }^{2}$ Budiyono Budiyono and Siti Khoiriah, Negara Hukum Dan Demokrasi, 1st ed. (Bandar Lampung: Zam-Zam Towers, 2017).

${ }^{3}$ Edward Aspinall and Marcus Mietzner, "Indonesia’s Democratic Paradox: Competitive Elections amidst Rising Illiberalism," Bulletin of Indonesian Economic Studies 55, no. 3 (2019): 295-317, https://doi.org/10.1080/00074918.2019.1690412.

${ }^{4}$ Mochtar Masoed, Negara, Kapital Dan Demokrasi (Yogyakarta: Pustaka Pelajar, 2003).

${ }^{5}$ Masoed.

${ }^{6}$ ulla Fiona And Francis E. Hutchinson, “Indonesia’s 2019 Elections: A Fractured Democracy?,” Asian Affairs 50, no. 4 (2019): 502-19, https://doi.org/10.1080/03068374.2019.1672400.

${ }^{7}$ Mukhtar Sarman, "Menakar Kualitas Pilkada: Menstrukturkan Sebuah Kontestasi Politik Yang Berintegritas," Jurnal Etika Dan Pemilu 1, no. 2 (2015): 7-21, https://dkpp.go.id/wpcontent/uploads/2019/01/jurnal_etika_vol1_no2.pdf.

8 Arifudin, "Penetapan Pemilih Pada Pemilihan Kepala Daerah Serentak Dalam Perspektif Demokrasi Konstitusional," Jurnal Etika Dan Pemilu 1, no. 2 (2015): 36-49, https://dkpp.go.id/wpcontent/uploads/2019/01/jurnal_etika_vol1_no2.pdf.
} 
realize the integrity of the election, of course, requires contributions from various actors. ${ }^{9}$ Democracy is seen as a political system and the best way of regulating people's lives. ${ }^{10}$

Different judges' considerations regarding the meaning of "simultaneous" in the design of election management arrangements in Indonesia, namely the Constitutional Court Decision Number 14/PUU-XI/2013 and the Constitutional Court Decision Number 55/PUU-XVII/2019. The Constitutional Court Decision Number 14/PUU-XI/2013 states that is constitutional by combining the election of the President, Vice President, House of People's Representative's or Dewan Perwakilan Rakyat (DPR) Members, Regional Representative Council or Dewan Perwakilan Daerah (DPD) Members, and Regional People's Representative Assembly or Dewan Perwakilan Rakyat Daerah (DPRD) Members simultaneously. Moreover, the Constitutional Court Decision Number 55/PUU-XVII/2019 states the constitutional election of President, Vice President President, Member of DPR, Member of DPD.

The election administration's arrangement significantly illustrates the difference in the judges' considerations between the Constitutional Court Decision Number 14/PUU-XI/2013 and the Constitutional Court Decision Number 55/PUU-XVII/2019, thus showing the dynamics of the simultaneous election design arrangement based on the two decisions. Of course, many issues need to be evaluated to create elections with integrity in the future. ${ }^{11}$

Based on a review of the judges' considerations, the Constitutional Court Decision Number 14/PUU-XI/2013 and the Constitutional Court Decision Number 55/PUU-XVII/2019. For this reason the author will examine in more depth the consistency of the judges' considerations of the two decisions and describe the suitability of the election implementation design based on the original intent in the 1945 Constitution.

\section{Problem identification}

By seeing the description above that has been stated in the background, the main topics studied above are: Are the judges' considerations in the Constitutional Court Decision Number 14/PUU-XI/2013 and the Constitutional Court Decision Number 55/PUU-XVII/2019 consistent and following the implementation design according to the 1945 Constitution?

\section{Research Method}

Normative legal research will be use in this research supported by the case approach, statute approach, and the historical approach. The legal approach is carried out by reviewing all laws and regulations relating to the primary considerations of judges who decide on general election cases. The historical approach is carried out by examining the background of the considerations of judges who decide election cases in Indonesia, interpreting the constitution based on original intent. Therefore, "simultaneously" in Article 22E of the 1945 Constitution of the Republic of Indonesia's definition will be explored by opinions behind the provision.

\section{B. Discussion}

Article 1 paragraph (2) of the 1945 Constitution of the Republic of Indonesia states that sovereignty belongs to the people and is exercised according to the constitution. Technically procedural is carried out as regulated in the 1945 Constitution. This can be seen from several

\footnotetext{
${ }^{9}$ Pramono, "Negara, Civil Society, Dan Upaya Mewujudkan Pemilu Berintegritas Di Indonesia," Jurnal Bawaslu, 2016, 5-31.

${ }^{10}$ Iwan Satriawan, "Modifikasi Sistem Hukum Pemilu Dalam Mewujudkan Pemilu Yang Berintegritas," Jurnal Etika Dan Pemilu 5, no. 1 (2019): 7-16, https://dkpp.go.id/wp-content/uploads/2020/01/jurnal-Etika-Pemilu_vol5_no.1_des_2019_A4_rev06122019_06122019-FINAL-OK-2_reduce-min.pdf.

${ }^{11}$ Abdul Wahid, “'Ius Constituendum' Penegakan Hukum Pidana Pemilu,” Jurnal Etika Dan Pemilu 5, no. 1 (2019): 17-26, https://dkpp.go.id/wp-content/uploads/2020/01/jurnal-Etika-Pemilu_vol5_no.1_des_2019_A4_rev06122019_06122019-FINAL-OK-2_reduce-min.pdf.
} 
indicators contained in the constitution. ${ }^{12}$ The arrangement of the types of elections by the Constitutional Court aims to make the electoral system better and capable of producing quality ones $^{13}$, General elections, also known as democratic parties, are parties related to sovereignty or power. ${ }^{14}$

State administrators are people who are considered qualified to carry out the life of the nation and state. ${ }^{15}$ In the concept of the rule of law in Article 1 Paragraph (1) of the 1945 Constitution of the Republic of Indonesia, it is a democratic legal state (democratische rechtstaat) and at the same time a democratic state based on the law (constitutional democracy) which is inseparable from one another. ${ }^{16}$

The authority of the Constitutional Court as one of the judicial institutions is a form of the implementation of a balance of power system between state institutions (checks and balances) so that it is called the Sole Interpreter of the Constitution. ${ }^{17}$.

The discussion on elections began at the Republic of Indonesia constitution's second amendment at the 2000 MPR annual session, held on 7-8 August 2000 once every five years. Regarding paragraph (2), which reads, General elections are held to elect members of the People's Representative Council, Regional Representative Council, President and Vice President and Regional People's Representative Council simultaneously throughout the Unitary State of the Republic of Indonesia. ${ }^{18}$ The synchronization meeting of PAH I BP MPR took place on Tuesday, July 11, 2000, which stated that there was no agreement on the sentence "simultaneously throughout the Unitary State of the Republic of Indonesia". Regarding this, The National Nahdlatul Ulama Committee said: ${ }^{19}$ When the DPR is elected, does the general administration mean the DPD and DPRD or the DPR, DPD, and DPRD simultaneously? What does the word "simultaneously" mean? Because some think the DPRD and the DPR RI will separate the DPD and the DPR RI's election. Therefore, there will be no State Institutions that end their term together. So, there is an inconsistency."

F-UN said that the sentence "simultaneously" and so on should be deleted. "I suggest regarding this article, in the election we just remember with the consideration that let us arrange whether this can later be carried out simultaneously throughout the selected Indonesia or not, we will arrange it later in the Regional Autonomy Law or in the Law on Regional Autonomy. This Basic Law is sufficient to the words of the Regional Representative Council". ${ }^{20}$ The meeting was resumed at the 2000 MPR Annual Session held on August 10, 2000. This meeting set a plan for the MPR factions' general view on the results of the MPR BP the proposal for the formation of commissions.

12 Yana Suryana, "Pengaruh Pelaksanaan Pemilihan Umum Serentak Terhadap Budaya Politik," Supremasi Hukum: Jurnal Penelitian Hukum 29, no. 1 (2020): 13-28, https://ejournal.unib.ac.id/index.php/supremasihukum/article/view/10116.

${ }^{13}$ Ratnia Solihah, "Peluang Dan Tantangan Pemilu Serentak 2019 Dalam Perspektif Politik," Jurnal Ilmiah Ilmu Pemerintahan 3, no. 1 (October 9, 2018): 73, https://doi.org/10.14710/jiip.v3i1.3234.

14 Abdul Wahid, "Kultur Mengistimewakan Pemodal Dapat Menciderai Pesta Demokrasi," Jurnal Etika Dan Pemilu 3, no. 2 (2017): 47.

${ }^{15}$ Zulfikri Suleman, "Mahkamah Etik Penyelenggara Negara Di Negara Demokrasi," Jurnal Etika Dan Pemilu 1, no. 1 (2015): 7-16, http://dkpp.go.id/wp-content/uploads/2019/01/Mahkamah-Etik-Penyelenggara-Negarajurnaletikavol1 no1.pdf.

16 Zulkarnain Ridlwan, "Negara Hukum Indonesia Kebalikan Nachtwachterstaat," FIAT JUSTISIA:Jurnal Ilmu Hukum 5, no. 2 (March 21, 2014), https://doi.org/10.25041/fiatjustisia.v5no2.56.

${ }^{17}$ Miftakhul Huda, "Ultra Petita Dalam Pengujian Undang-Undang," Jurnal Konstitusi 4, no. 3 (2007).

${ }^{18}$ Mahkamah Konstitusi, Naskah Komprehensif Perubahan Undang-Undang Dasar Negara Republik Indonesia Tahun 1945: Latar Belakang, Proses, Dan Hasil Pembahasan, 1999-2002 : Buku I-X (Jakarta: Sekretariat Jenderal dan Kepaniteraan MKRI, 2010).

${ }^{19}$ Mahkamah Konstitusi.

${ }^{20}$ Mahkamah Konstitusi. 
Based on the description above, a search of the document will find the arguments of A. M. Lutfi, who proposes the formulation of the chapter entitled "General Elections" to be carried out simultaneously throughout Indonesia. ${ }^{21}$ Meanwhile, the materials proposed by Faction Party of National Awakening Party (F-KB) to fill the election chapter are as follows:

"The next one relates to this area. There will be elections held for the election of governors, regents, and or mayors. Of course, the time cannot be determined because it involves the service period of each of them. Third, it concerns the principle of holding elections simultaneously, both national and local, carried out, to be honest, fair, direct, general, accessible, and confidential".

In the second amendment, there was no agreement on including an election in the 1945 Constitution. In the third amendment, the MPR annual session, which was held on November 1-9, 2001, the discussion began at the Commission a Meeting of the MPR Annual Session, on November 5, 2001, members of the Indonesian National Unity Faction (F-KKI) questioned the reasons for including the election of President and Vice President in terms of the general election, chairman of the meeting and at the same time deputy chairman of PAH I BP MPR, The National Nahdlatul Ulama Committee explained as follows:

"So it's like this, indeed on this concept, as a whole, the president later in the so-called direct election will be abolished in the general election held together when choosing the DPR, $D P D$, then DPRD, then also the President and Vice President packages, so that in the picture later there are five boxes. So the box for the DPR RI, the box for the DPD, the box for the Provincial DPRD, the box for the City or Regency DPRD, and the box for the President and Vice President. So the picture is indeed that and responding to this concept calls the election of the President and Vice President in the general election".

Regarding The National Nahdlatul Ulama Committee answer, Indonesian National Unity Faction wanted the general election to be separated from the election for President and Vice President. Soetanto essentially said:

"Then regarding the General Election, which is paragraph (2), we still want the presidential election and the general election to be separated. Then the presidential election can also be followed by the election of governors, regents, mayors".

Based on a review of the comprehensive text of the amendments to the 1945 Constitution in book five on elections, the author sees that the debate about the word "simultaneously" raises pros and cons when included in the article's content. ${ }^{22}$ The word "simultaneous" has two views, the first view regarding the meaning of simultaneously, meaning that the election of the President and Vice President together with other ballot boxes. The second view is that the election is divided into two, namely national and local, national to elect the President and Vice President and members of the DPD. Members of the DPR and then local to elect Members of DPRD, Governors, Mayors, Regents.

The opinions of the factions in the process of amending the 1945 Constitution of the Republic of Indonesia were separated into two views, the factions who thought that the word "simultaneous" should be combined according to the Deputy Chairperson of PAH I BP MPR, Indonesian Democratic Party of Struggle Faction (F-PDIP). On second opinion is the

\footnotetext{
${ }^{21}$ Edward Aspinall and Marcus Mietzner, “Indonesian Politics in 2014: Democracy's Close Call," Bulletin of Indonesian Economic Studies 50, no. 3 (2014): 347-469, https://doi.org/10.1080/00074918.2014.980375.

${ }^{22}$ Mahkamah Konstitusi, Naskah Komprehensif Perubahan Undang-Undang Dasar Negara Republik Indonesia Tahun 1945 : Latar Belakang, Proses, Dan Hasil Pembahasan, 1999-2002 : Buku I-X.
} 
simultaneous elections are separated into two models as Indonesian National Unity Faction (FKKI), Faction Party of National Awakening Party (F-KB), Crescent Star Party Faction (FPBB). These ideas lead to different arguments.

So based on the results of the search for the 1999-2002 MPR PAH Session, no agreement was found on the original intent of the meaning of "simultaneously" explicitly in Article 22E of the 1945 Constitution. The meaning of "simultaneously" is not meant for the type of election. So that voters vote simultaneously, as for the type of election, it can be an election.

The idea of favouring simultaneous or combined elections sees efficient work and maximum results and avoids social and political risks that we might not want. ${ }^{23}$ This opinion has strong arguments. Another view that postulates the separation of the simultaneous election model into national and local is related to the term of office to be elected. ${ }^{24}$

In the judge's consideration in the Constitutional Court Decision Number 14/PUU-XI/2013, they considered that:

First, the constitutionality of holding the presidential election, whether after or at the same time as the election for members of the representative body, must at least pay attention to three primary considerations, namely the relationship between the electoral system and the choice of a presidential government system, the original intent of the makers of the 1945 Constitution, the effectiveness and efficiency of the general election administration, and the right of citizens to choose intelligently. ${ }^{25}$

Second, both in terms of the original intent method of interpretation and systematic interpretation and comprehensive grammatical interpretation, the Presidential Election is held simultaneously with general elections to elect members of representative institutions. ${ }^{26}$

Third, in interpreting the provisions of the 1945 Constitution regarding the constitutional structure and government system, the provider uses a comprehensive method to understand the norms of the 1945 Constitution. This method aims to avoid overly broad interpretations because it involves the design of the government and state administration system desired in the prevailing norms of the 1945 Constitution as a written constitution. ${ }^{27}$

Furthermore, based on the conclusion of the Constitutional Court Decision Number 14/PUU-XI/2013, the Court enforces the holding of the Presidential Election and the Election of Members of Representative Institutions simultaneously to elect the President, Vice President, DPR Members, DPD Members, DPRD Members simultaneously.

From the author's search on the judges' considerations, one of the constitutional requirements for combining the presidential election with the election of representative members is the intended interpretation method. After being traced in the previous discussion, no agreement underlies the implementation of general elections to elect the President, Vice President, Members of DPR, Members of DPD, Members of DPRD simultaneously or not. The amendments to the 1945 Constitution were attended by factions in the 1999-2002 MPR PAH Session. There were differences of opinion as well as debates. Simultaneous holding elections is a democratic party held in several regions and an executor of people's sovereignty in the

\footnotetext{
${ }^{23}$ Blane D Lewis, "How Do Mayors Get Elected? The Causal Effects of Pre-Electoral Coalitions on Mayoral Election Outcomes in Indonesia," Local Government Studies 46, no. 3 (2020): 394-413, https://doi.org/10.1080/03003930.2019.1627334.

${ }^{24}$ Yanwar Pribadi, "The 2018 and 2019 Indonesian Elections: Identity Politics and Regional Perspectives," South East Asia Research 29, no. 2 (2021): 271-74, https://doi.org/10.1080/0967828X.2021.1932914.

${ }^{25}$ Vide Putusan Mahkamah Konstitusi Nomor: 14/PUU-XI/2013, pg. 78

${ }^{26}$ Constitutional Court Decision

${ }^{27}$ Constitutional Court Decision
} 
unitary state of the Republic of Indonesia. ${ }^{28}$ Consideration of Judges Decision of the Constitutional Court Number 55/PUU-XVII/2019 stated the following matters:

First, by carefully understanding the Simultaneous Elections as argued by the Petitioners, the Court considers three basic constructions by referring to the Constitutional Court Decision Number 14/PUU-XI/2013. This decision states that the holding of Simultaneous Elections is constitutional, with one of the bases for judging the constitutionality of Simultaneous Elections. It is based on the original intent of the 1945 Constitution. ${ }^{29}$

The Court's indecision reflects the emergence of legal uncertainty. If in the previous decision, namely the Constitutional Court Decision Number 14/PUU-XI/2013, it has been stated that it is constitutional in merging the election of the President, Vice President, and members of the DPR DPD, DPRD at the same time. So, it is best not to change the provisions again so that the decision is consistent. The judge's job is to decide every case brought before him, so he must consider the juridical truth with the philosophical truth. ${ }^{30}$

According to the author, this interpretation generally uses an original intent method approach to constitutional norms. The originalists have powerful reasons in believing that there is nothing more precisely to explain the constitution's intent than the framers of the constitution themselves. ${ }^{31}$ When there is a problem related to the constitution, the statements of the formulators/constitutional drafters can significantly influence the judge in his decision compared to the statements of other parties. It is time for this nation to get out of the old paradigm that is based on views. ${ }^{32}$

Furthermore, in the decision of the Constitutional Court Number 55/PUU-XVII/2019. The Constitutional Court provides several models of simultaneous general elections which are still considered constitutional based on the 1945 Constitution, namely:

1) Simultaneous general elections to elect members of DPR, DPD, President/Vice President, and members of DPRD.

2) Simultaneous general elections to elect members of DPR, DPD, President/Vice President, Governor, and Regent/Mayor.

3) Simultaneous general elections to elect members of DPR, DPD, President/Vice President, DPRD members, Governor, and Regent/Mayor.

4) Simultaneous national elections to elect members of DPR, DPD, President/Vice President and sometime after that, local simultaneous general elections are held to elect members of Provincial DPRD, Regency/City DPRD members, the election of Governors, and Regents/Mayors.

5) Regency/City and elect the Regent and Mayor. Simultaneous national elections elect members of the DPR, DPD, President/Vice President, and a simultaneous provincial general election. This is held to elect members of the Provincial DPRD and elect the Governor. Sometimes, after that, simultaneous district/city general elections are held to elect members of the DPR.

6) Other options as long as the general election is held simultaneously to elect members of DPR, DPD and President/Vice President.

\footnotetext{
${ }^{28}$ Firman, "Etika Menjaga Netralitas Dan Imparsialitas Bagi Birokrasi Dan Pimpinan Penyelenggara Pemilu," Jurnal Etika Dan Pemilu 1, no. 3 (2015): 20-30, https://dkpp.go.id/wp-content/uploads/2019/01/NetralitasImparsialitas-PNS-jurnaletikavol1 no3.pdf.

${ }^{29}$ Putusan Mahkamah Konstitusi Nomor: 55/PUU-XVII/2019

30 Mariyadi Faqih, "Relasi Ratio Decidendi Dengan Keyakinan Hakim Mk Dalam Putusan Perselisihan Pemilukada," Jurnal Etika Dan Pemilu 1, no. 1 (2015), https://dkpp.go.id/wpcontent/uploads/2019/01/Mahkamah-Etik-Penyelenggara-Negara-jurnaletikavoll no1.pdf.

31 Michael Buehler, Ronnie Nataatmadja, and Iqra Anugrah, "Limitations to Subnational Authoritarianism: Indonesian Local Government Head Elections in Comparative Perspective," Regional \& Federal Studies 31, no. 3 (2021): 381-404, https://doi.org/10.1080/13597566.2021.1918388.

${ }^{32}$ Suyanto Londrang, "Pengaruh Pilkada Serentak Terhadap Pertumbuhan Demokrasi Di Indoensia," Jurnal Etika Dan Pemilu 1, no. 2 (2015): 50-67, https://www.scribd.com/document/327021760/Jurnal-Etika-Vol1-No2.
} 
So the Constitutional Court Decision Number: 55/PUU-XVII/2019 states that it is constitutional by synchronizing the general election for members of representative institutions (DPR, DPD, DPRD) with the general election of the President and Vice President.

The Constitutional Court's decision Number: 14/PUU-XI/2013 initially mentioned the simultaneous election of DPRD members in the simultaneous election, and the Constitutional Court's Decision Number: 55/PUU-XVII/2019 was changed without electing DPRD members simultaneously in the simultaneous election. In the decision consistency's absence of firmness, the Court should not postulate that on the judges' considerations to maintain the decision. If the fundamental values that become the guidelines are correctly applied, no more deviant behaviour will occur. ${ }^{33}$

When the Constitutional Court decided to hold Simultaneous Elections, the Constitutional Court's Decision Number: 14/PUU-XI/2013 was not yet an operational decision that answered concerns over various problems in the administration of elections so far. Various reasons such as: so that the voting community is not saturated, minimizing money politics, minimizing politicization of the bureaucracy, and efficiency in its implementation may be answered.

\section{Conclusion}

The results of the author's analysis and research regarding the dynamics of the design arrangement for holding simultaneous elections, based on the Constitutional Court Decision 14/PUU-XI/2013, are inconsistent with the Constitutional Court Decision 55/PUU-XVII/2019. Based on the original intent study, the Amendrs to the 1945 Constitution of the Republic of Indonesia disagreed on the simultaneous implementation of the General Election in Indonesia. So the judge's consideration in the Constitutional Court's decision Number 14/PUU-XI/2013, which requires simultaneous elections, is not under the design of the election administration according to the amendment to the 1945 Constitution of the Republic of Indonesia. Six alternatives for the simultaneous implementation of elections. So this is the original intent following the 1945 Constitution of the Republic of Indonesia, in which the choice of an election with five (5) ballot boxes which has been the only choice according to the Constitutional Court Decision 14/PUU-XI/2013, has been refined by the Constitutional Court's decision Number 55/PUU- XVII/2019.

\section{Bibliography}

\section{A. Journal}

Arifudin. "Penetapan Pemilih Pada Pemilihan Kepala Daerah Serentak Dalam Perspektif Demokrasi Konstitusional." Jurnal Etika Dan Pemilu 1, no. 2 (2015): 36-49. https://dkpp.go.id/wp-content/uploads/2019/01/jurnal_etika_vol1_no2.pdf.

Aspinall, Edward, and Marcus Mietzner. "Indonesia's Democratic Paradox: Competitive Elections amidst Rising Illiberalism." Bulletin of Indonesian Economic Studies 55, no. 3 (2019): 295-317. https://doi.org/10.1080/00074918.2019.1690412.

- "Indonesian Politics in 2014: Democracy's Close Call." Bulletin of Indonesian Economic Studies 50, no. 3 (2014): https://doi.org/10.1080/00074918.2014.980375.

Buehler, Michael, Ronnie Nataatmadja, and Iqra Anugrah. "Limitations to Subnational Authoritarianism: Indonesian Local Government Head Elections in Comparative Perspective." Regional \& Federal Studies 31, no. 3 (2021): 381-404.

${ }^{33}$ Ahmad Dawam Pratiknyo, "Moral Politik Dalam Mewujudkan Pemilu Yang Demokratis," Jurnal Etika Dan Pemilu 3, no. 2 (2017). 
https://doi.org/10.1080/13597566.2021.1918388.

Faqih, Mariyadi. "Relasi Ratio Decidendi Dengan Keyakinan Hakim Mk Dalam Putusan Perselisihan Pemilukada." Jurnal Etika Dan Pemilu 1, no. 1 (2015). https://dkpp.go.id/wpcontent/uploads/2019/01/Mahkamah-Etik-Penyelenggara-Negarajurnaletikavol1no1.pdf.

Fiona, Ulla, and Francis E. Hutchinson. "Indonesia's 2019 Elections: A Fractured Democracy?" Asian Affairs 50, no. 4 (2019): 502-19. https://doi.org/10.1080/03068374.2019.1672400.

Firman. "Etika Menjaga Netralitas Dan Imparsialitas Bagi Birokrasi Dan Pimpinan Penyelenggara Pemilu." Jurnal Etika Dan Pemilu 1, no. 3 (2015): 20-30. https://dkpp.go.id/wp-content/uploads/2019/01/Netralitas-Imparsialitas-PNSjurnaletikavol1no3.pdf.

Huda, Miftakhul. "Ultra Petita Dalam Pengujian Undang-Undang." Jurnal Konstitusi 4, no. 3 (2007).

Lewis, Blane D. "How Do Mayors Get Elected? The Causal Effects of Pre-Electoral Coalitions on Mayoral Election Outcomes in Indonesia." Local Government Studies 46, no. 3 (2020): 394-413. https://doi.org/10.1080/03003930.2019.1627334.

Londrang, Suyanto. "Pengaruh Pilkada Serentak Terhadap Pertumbuhan Demokrasi Di Indoensia." Jurnal Etika Dan Pemilu 1, no. 2 (2015): 50-67. https://www.scribd.com/document/327021760/Jurnal-Etika-Vol1-No2.

Pramono. "Negara, Civil Society, Dan Upaya Mewujudkan Pemilu Berintegritas Di Indonesia." Jurnal Bawaslu, 2016, 5-31.

Pratiknyo, Ahmad Dawam. "Moral Politik Dalam Mewujudkan Pemilu Yang Demokratis." Jurnal Etika Dan Pemilu 3, no. 2 (2017).

Pribadi, Yanwar. "The 2018 and 2019 Indonesian Elections: Identity Politics and Regional Perspectives." South-East Asia Research 29, no. 2 (2021): 271-74. https://doi.org/10.1080/0967828X.2021.1932914.

Ridlwan, Zulkarnain. "Negara Hukum Indonesia Kebalikan Nachtwachterstaat." FIAT JUSTISIA:Jurnal Ilmu Hukum 5, no. 2 (March 21, 2014). https://doi.org/10.25041/fiatjustisia.v5no2.56.

Sarman, Mukhtar. "Menakar Kualitas Pilkada: Menstrukturkan Sebuah Kontestasi Politik Yang Berintegritas." Jurnal Etika Dan Pemilu 1, no. 2 (2015): 7-21. https://dkpp.go.id/wpcontent/uploads/2019/01/jurnal_etika_vol1_no2.pdf.

Satriawan, Iwan. "Modifikasi Sistem Hukum Pemilu Dalam Mewujudkan Pemilu Yang Berintegritas." Jurnal Etika Dan Pemilu 5, no. 1 (2019): 7-16. https://dkpp.go.id/wpcontent/uploads/2020/01/jurnal-Etika-Pemilu_vol-

5_no.1_des_2019_A4_rev06122019_06122019-FINAL-OK-2_reduce-min.pdf.

Solihah, Ratnia. "Peluang Dan Tantangan Pemilu Serentak 2019 Dalam Perspektif Politik." Jurnal Ilmiah Ilmu Pemerintahan 3, no. 1 (October 9, 2018): 73. https://doi.org/10.14710/jiip.v3i1.3234.

Suleman, Zulfikri. "Mahkamah Etik Penyelenggara Negara Di Negara Demokrasi." Jurnal Etika Dan Pemilu 1, no. 1 (2015): 7-16. http://dkpp.go.id/wpcontent/uploads/2019/01/Mahkamah-Etik-Penyelenggara-Negarajurnaletikavol1no1.pdf.

Suryana, Yana. "Pengaruh Pelaksanaan Pemilihan Umum Serentak Terhadap Budaya Politik." Supremasi Hukum: Jurnal Penelitian Hukum 29, no. 1 (2020): 13-28. https://ejournal.unib.ac.id/index.php/supremasihukum/article/view/10116.

Wahid, Abdul. “'Ius Constituendum' Penegakan Hukum Pidana Pemilu.” Jurnal Etika Dan Pemilu 5, no. 1 (2019): 17-26. https://dkpp.go.id/wp-content/uploads/2020/01/jurnalEtika-Pemilu_vol-5_no.1_des_2019_A4_rev06122019_06122019-FINAL-OK- 
2_reduce-min.pdf.

. "Kultur Mengistimewakan Pemodal Dapat Menciderai Pesta Demokrasi." Jurnal Etika Dan Pemilu 3, no. 2 (2017): 47.

\section{B. Books}

Asshiddiqie, Jimly. Kedudukan Mahkamah Konstitusi Dalam Struktur Ketatanegaraan Indonesia. Semarang: Pustaka Utama, 2015.

Budiyono, Budiyono, and Siti Khoiriah. Negara Hukum Dan Demokrasi. 1st ed. Bandar Lampung: Zam-Zam Towers, 2017.

Mahkamah Konstitusi. Naskah Komprehensif Perubahan Undang-Undang Dasar Negara Republik Indonesia Tahun 1945 : Latar Belakang, Proses, Dan Hasil Pembahasan, 1999 2002 : Buku I-X. Jakarta: Sekretariat Jenderal dan Kepaniteraan MKRI, 2010.

Masoed, Mochtar. Negara, Kapital Dan Demokrasi. Yogyakarta: Pustaka Pelajar, 2003.

\section{Regulations}

Constitutional Court Decision No: 14/PUU-XI/2013

Constitutional Court Decision No: 55/PUU-XVII/2019 